\title{
電気泳動実験による モルタル中の塩化物イオン拡散係数の推計
}

\author{
大即信明 ${ }^{1} \cdot$ 久田 真 $^{2} \cdot$ 大谷隆之 $^{3} \cdot$ 丸山俊夫 $^{4}$
}

\begin{abstract}
'正会員 工博 東京工業大学教授 工学部開発システム工学科（テ152-8552 東京都目黒区大岡山 2-12-1）
${ }^{2}$ 正会員 博 (工) 東京工業大学助手 工学部開発システム工学科（テ152-8552 東京都目黒区大岡山 2-12-1）

${ }^{3}$ 正会員 五洋建設株式会社 東京支店（テ140-0013 東京都品川区南大井6-26-3 大森ベルポートD館）

${ }^{4}$ 工博 東京工業大学教授 工学部金属工学科（干152-8552 東京都目黒区大岡山 2-12-1）
\end{abstract}

\begin{abstract}
コンクリート中における塩化物イオンの拡散係数を, 電気泳動実験より定性的あるいは定量的に求めよう とする試みは, 種々のものがあるものの, 明確にされていないのが現状である.この状況を鑑み, 本研究で は，モルタル中における拡散係数を、電気泳動実験より得られる絶対移動度より理論的に推計することを検

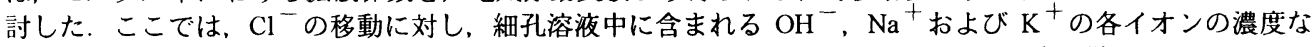
らびに移動方向が及ぼす影響を考慮した，特に，イオン濃度の影響については，溶液化学におけるDebyeHückel の理論を適用し，イオンの移動方向が及ぼす影響については, 電気的中性の条件を考虑して, コンク リート中の $\mathrm{Cl}^{-}$の拡散係数の推計方法を理論的に提示し, さらに, 実験によりこの方法の妥当性を示した.
\end{abstract}

Key Words: chloride ion, diffusion, migration, Einstein's equation, Nernst-Plank equation, Debye-Hückel theory, mobility, pore solution, electro newtrality

\section{1. 本研究の背景}

塩害において，コンクリート中での塩化物イオン (以下, $\mathrm{Cl}^{-}$) の拡散性状を把握することは極めて 重要である.

一般に，コンクリート中における $\mathrm{Cl}^{-}$の拡散性状 を表す場合には，Fick の拡散方程式が用いられてい る. 従来より行われている手法としては, 拡散セル を用い, $\mathrm{Cl}^{-}$の濃度変化を測定して, Fick の第 1 法 則を適用することにより $\mathrm{Cl}^{-}$の搪散係数を決定する 方法 ${ }^{2}$ がある. また，その他の手法としては，コン クリート表面から深さ方向に $\mathrm{Cl}^{-}$の濃度分布を測定 し，Fick の第 2 法則を適用することにより拡散係数 を決定する方法もある。これらは拡散性状の定量的 把握が可能であるものの，長い時間を要するのが一 般的である.

ところで，電気を用いてコンクリート中の $\mathrm{Cl}^{-}$の 搪散性状を把握し，これによりコンクリート中にお ける $\mathrm{Cl}^{-}$の浸透抵抗性を評価する試みが, ASTM C 1202-91 ${ }^{3)}$ で示されている。この規格は， $\mathrm{Cl}^{-}$の拡散 性状を短期間で把握できる利点があるが，コンクリ
一トの $\mathrm{Cl}^{-}$浸透抵抗性の評価が定性的であり, 通過 電荷量と $\mathrm{Cl}^{-}$拡散性状の関連性が不明確である ${ }^{4)}$ 之 指摘されている。 また，著者らは，ASTM C 1202-91 とほぼ同様のシステムを用いて，短時間かつ定量的 な拉散性状の把握を行う試み ${ }^{5)}$ を行ったが, イオン 濃度，イオン間の相互作用を考慮していないため, 定性的な範囲にとどまっていた。このため，本論文 では，物質移動の一般式である Nernst-Plank 式と， 拡散之電気泳動を関連つける Eistein の関係式, 溶液 の濃度に関する Debye-Hückel の理論および溶液中の イオンの移動に関する電気的中性条件を用いること により拡散係数を求めようとするものである.

\section{2. 現状での問題点および本研究の目的}

抎散および電気泳動の関連性を論じる上で，それ らを関連づけ式をどのように適用するかが重要に なってくると思われる. 現状での問題点の一つは, 適用している関係式の妥当性であろう. Eistein の関 係式は希薄溶液のみで成立する ${ }^{6)}$ にも関わらず，一 般に $\mathrm{pH}=12$ 以上の強電解質であるコンクリート中の 細孔溶液に対して適用しており，この点に関しての 


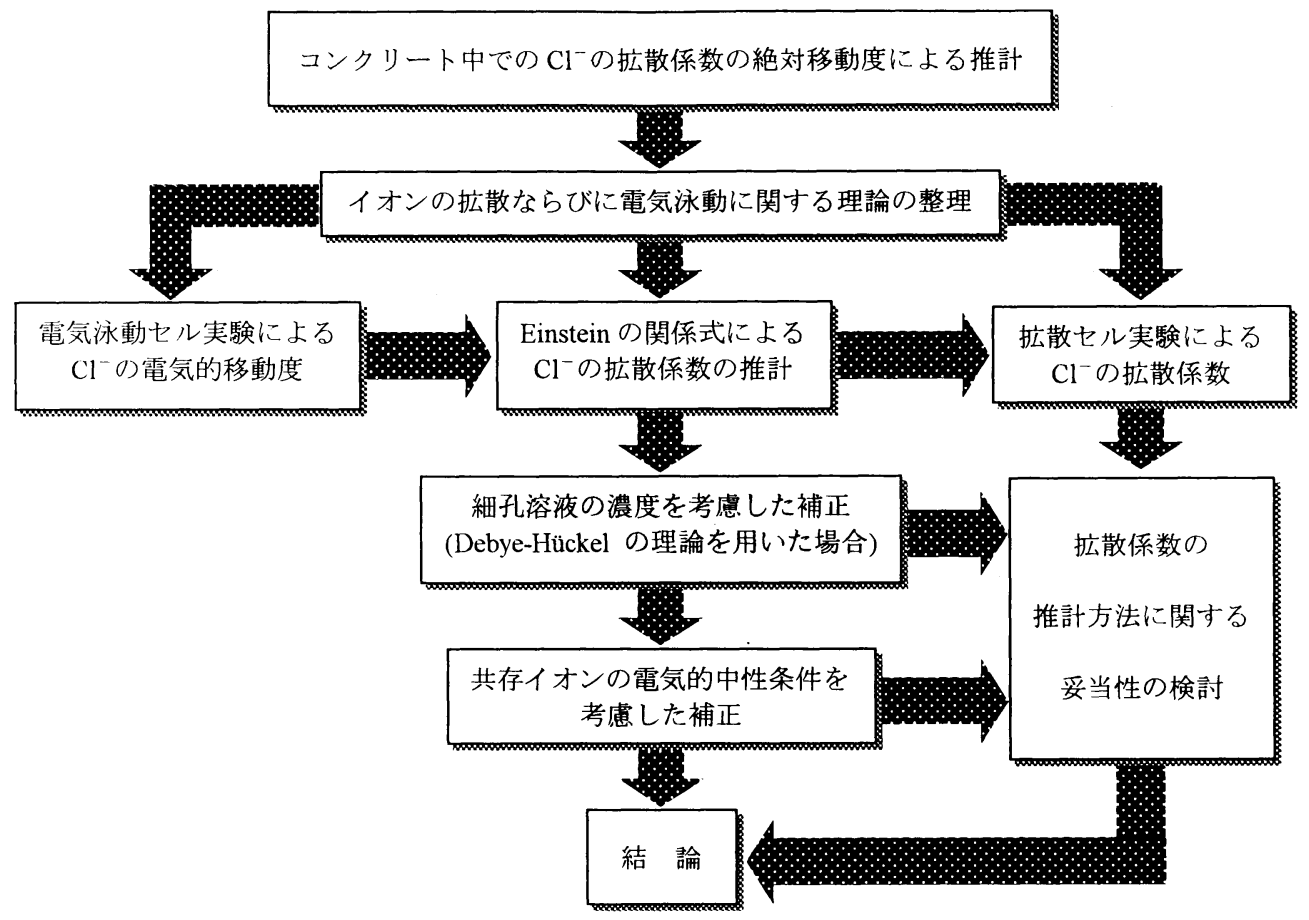

図-1 本研究のフロー

議論が必要であると思われる，また，細孔溶液のイ オン組成が $\mathrm{Na}^{+}, \mathrm{K}^{+}$および $\mathrm{OH}^{-}$など, 数種のイ オンで構成されているにも関わらず，それらの影響 を考慮しないで式を適用した点にも議論が必要で ある。

これらの問題点を考慮した上で, 本研究では, コ ンクリート内部で生じる $\mathrm{Cl}^{-}$の移動現象を駆動力 が濃度勾配である拡散現象之駆動力が電位勾配で ある電気泳動現象を理論的かつ実験的に検討し，拡 散係数を電気泳動セル実験で求められる絶対移動 度より推計することを目的とした。

\section{3. 本研究の構成}

本研究のフローを図-1に示す. まず, 理論的な見 地から搪散現象および電気泳動現象の整理を行い, 搪散および電気泳動の関連性を論じるには移動指 標として絶対移動度（本文 7.にて論述する）を用 いることが適当であることを指摘した.

また, 電気泳動セル実験から得られる絶対移動度 と, 拡散セル実験から得られる拡散係数を比較・検 部した。
次に理論的見地からの検討を通じて得られた，細 孔溶液の濃度に関する補正および共存イオンの影 響に関する補正を行った拡散および電気泳動の関 係式を提案することにより, 拡散および電気泳動の 関連性を明確にした。

さらに, この関係式の妥当性を実験結果を用いて 検証し, 得られた知見をまとめ結論とした.

\section{4. 実験概要}

（1）供試体の配合および作製

a) 使用材料

一般に市販されている普通ポルトランドセメン トおよび細骨材を用いてモルタル供試体を作製し た. 本研究で用いたセメントの物理的性質および化 学成分を表-1 に, 細骨材の物理的性質を表-2 に示 す.なお，本研究で用いた水はすべて蒸留水である b) 配合

本研究で基準となる供試体は，W/C=0.5, S/C $=2.5$ のモルタルである.これを基準に物理的性質および 化学的性質（細孔溶液のアルカリイオン濃度）を変 化させ，それらの性質の違いがモルタル中における 
表-1 セメントの物理的性質ならびに化学成分

\begin{tabular}{|c|c|c|}
\hline \multicolumn{3}{|l|}{ 物理的性質 } \\
\hline 比重 & & 3.15 \\
\hline 比表面積 & $\mathrm{cm}^{2} / \mathrm{g}$ & 3260 \\
\hline 凝結 始発 & h-min & $2-22$ \\
\hline 終結 & h-min & $3-55$ \\
\hline 安定性 & - & 良 \\
\hline 圧縮強さ 3 日 & $\mathrm{N} / \mathrm{mm}^{2}$ & 16.6 \\
\hline 7 日 & $\mathrm{N} / \mathrm{mm}^{2}$ & 26.7 \\
\hline 28 日 & $\mathrm{N} / \mathrm{mm}^{2}$ & 42.7 \\
\hline \multicolumn{3}{|l|}{ 化学成分 } \\
\hline Ig. Loss & $\%$ & 1.5 \\
\hline $\mathrm{MnO}$ & $\%$ & 1.9 \\
\hline $\mathrm{SO}_{3}$ & $\%$ & 1.4 \\
\hline $\mathrm{Na}_{2} \mathrm{O}$ eq. & $\%$ & 0.62 \\
\hline $\mathrm{Cl}$ & $\%$ & 0.005 \\
\hline
\end{tabular}

表-2 細骨材の物理的性質

\begin{tabular}{l|c}
\hline 産地・種類 & 千葉県小櫝産山砂 \\
\hline 表乾比重 & 2.62 \\
\hline 吸水率 $(\%)$ & 1.17 \\
\hline 粗粒率 & 2.20 \\
\hline
\end{tabular}

表-3 本研究で用いたモルタルの配合表

\begin{tabular}{c|c|c|c}
\hline \multirow{2}{*}{ W/C } & \multicolumn{3}{|c}{ 単位量 $\mathrm{kg} / \mathrm{m}^{3}$} \\
\cline { 2 - 4 } & $\mathrm{W}$ & $\mathrm{C}$ & $\mathrm{S}$ \\
\hline 0.40 & 256 & 639 & 1400 \\
\hline 0.50 & 280 & 560 & 1400 \\
\hline 0.65 & 308 & 473 & 1400 \\
\hline
\end{tabular}

表-4 添加アルカリ $(\mathrm{NaOH})$ の量

\begin{tabular}{lllll}
\hline 添加量 $\mathrm{kmol} / \mathrm{m}^{3}$ & 0.00, & 0.13, & 0.26 \\
\hline
\end{tabular}

$\mathrm{Cl}$-の移動（拡散，電気泳動）に及ぼす影響程度の 把握を試みた。モルタルの物理的性質は W/C により 変化させ, $\mathrm{W} / \mathrm{C}=0.4$ および 0.6 のモルルについて は, 単位体積中のペースト量が $\mathrm{W} / \mathrm{C}=0.5, \mathrm{~S} / \mathrm{C}=2.5$ の モルタルと同一となるように $\mathrm{S} / \mathrm{C}$ を設定した. 本研 究で用いたモルタルの配合を表-3に示す．また，モ ルタルの細孔溶液中のアルカリイオン濃度は, 練混 ぜ水にあらかじめ $\mathrm{NaOH}$ 試薬を添加することにより
セメントと練混ぜ水を投入後パドルを回転
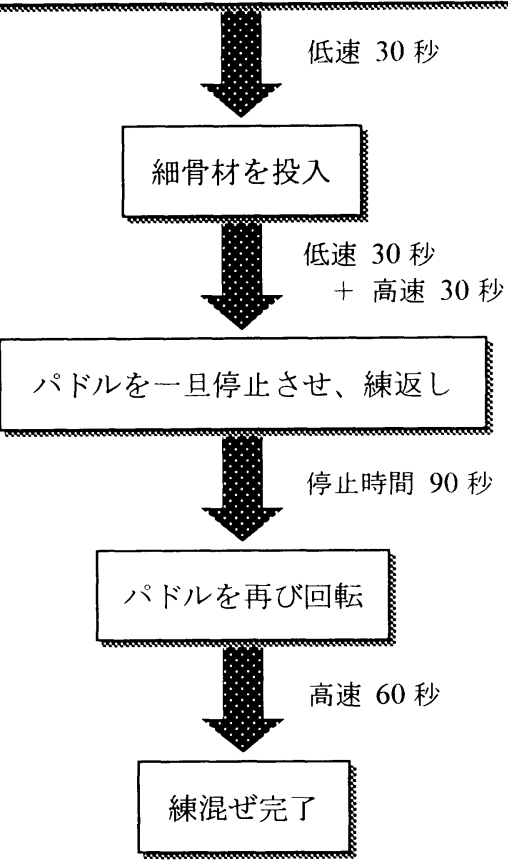

図-2 モルタル練混ぜ手順の概略

行った. $\mathrm{NaOH}$ 試薬の添加量を表-4 に示す.

\section{c) 供試体の作製および業生}

モルタルの練混ぜは, ISO-679 に準じて行った. 練混ぜ方法の概略を図-2 に示す， $\phi 10 \times 20 \mathrm{~cm}$ の円柱 型枠を用いて供試体を作製し， $24 \pm 2$ 時間後に脱型 した. 脱型後, 湿潤空気中 $\left(20 \pm 3^{\circ} \mathrm{C}\right.$, R.H. $90 \%$ 以上) で27日間養生を行った.

\section{(2) セル実験に関する概要}

4-(1)のように作製した供試体を, 厚さ $3 \mathrm{~cm}$ の円板 状になるようにダイヤモンドカッタを用いて切断し た。なお，供試体の打設面ならびに底面を含む部分 は実験には用いなかった．切断した円板状の供試体 を，同じ厚さのゴム製アタッチメント（図-3）に取 り付け, エポキシ系接着剂を用いて固定し, 漏水を 防いだ（以下，セル用供試体とする）。 セル用供試 体を，図-4に示すようにアクリル樹脂製円筒（容量 約 $900 \mathrm{ml}$ ）で挟み，溶液が漏れないように固定した。

\section{a) 電気泳動セル実験}

作製した電気泳動セルのアノード側に水酸化力ル シウム飽和水溶液, カソード側セルに塩化ナトリウ 


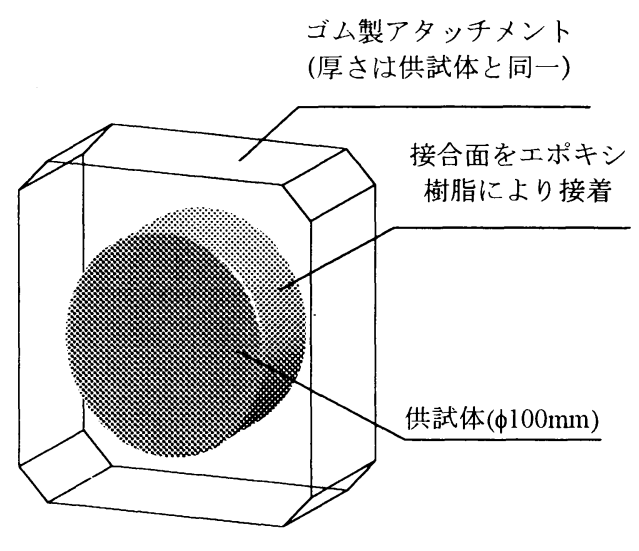

図-3 アタッチメントを装着した供試体の概略

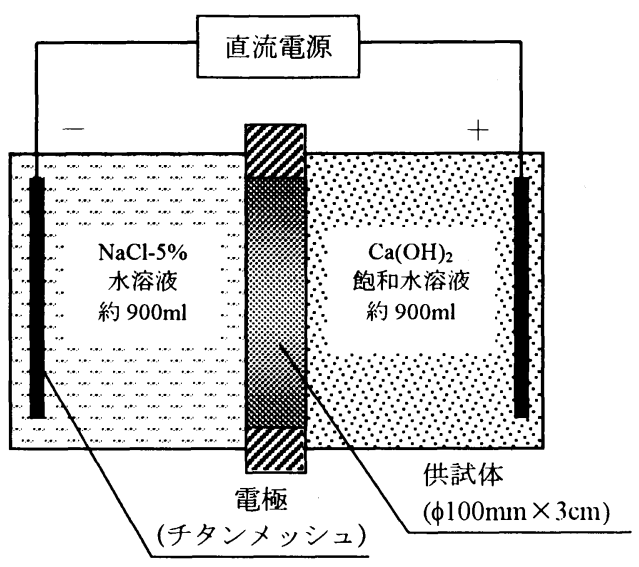

図-4 電気泳動セルの概略
ム-5\%水溶液を入れた後, チタンメッシュを電極と して通電を行った（図-4）。通電は，電流密度が常 に $1.0 \mathrm{~A} / \mathrm{m}^{2}$ になるように, 電流を制御して行った. なお，本実験では，濃度測定用試料溶液は，アノ一 ド側セル溶液 $\left(\mathrm{Ca}(\mathrm{OH})_{2}\right.$ 飽和水溶液 $)$ から採取した （以後, 被検出セル溶液とする）.

実験開始後, 被検出セル溶液を採取し $\mathrm{Cl}^{-}$濃度の 測定を行った。なお，セル内溶液量 $(900 \mathrm{ml})$ に対 して, 採取溶液量は $0.5 \mathrm{ml}$ と微量のため, 濃度補正 は行わなかった。

b) 拡散セル実験

拡散セルは，図-4に示すセルで，電極を用いない ものを準備した，供試体を中央のアタッチメントに 固定した拡散セルの一方に $\mathrm{Ca}(\mathrm{OH})_{2}$ 水溶液, 他方に $\mathrm{NaCl}-5 \%$ 水溶液を入れ，濃度勾配を生じさせた。な お, 拡散セル実験においても, 濃度測定用試料溶液 の濃度測定は, $\mathrm{Ca}(\mathrm{OH})_{2}$ 水溶液が入ったセルから採 取した溶液を用いた。

c) 対象イオン

本研究では， $\mathrm{Cl}$ - の挙動に影響を及ぼすと考えら れる硬化体中の細孔溶液に含まれるイオンである $\mathrm{OH}^{-}, \mathrm{Na}^{+}, \mathrm{K}^{+}$および $\mathrm{Ca}^{+}$を測定の対象イオン とした.

\section{d) 溶液のイオン濃度測定について}

あらかじめ $14.5 \mathrm{ml}$ の蒸留水をいれた棒ビンに, 被 檢出セル溶液 $0.5 \mathrm{ml}$ をホールピペットを用いて注入 し，十分に擋はんを行った後（30 倍希釈），イオン 濃度測定を行った。なお，イオン濃度測定には高速 液体イオンクロマトグラフを用いた.

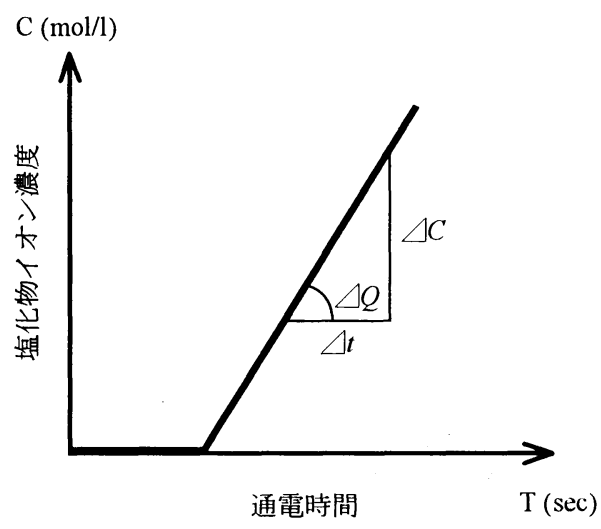

図-5 比検出側セルにおける $\mathrm{Cl}^{-}$の濃度変化

5. 電気泳動セル実験より得られる移動指標と 拡散セル実験より得られる移動指標の考え 方について

(1) セル実験におけるフラックスの考え方

電気泳動セル, 拡散セルいずれの場合も被検出側 セルにおける $\mathrm{Cl}^{-}$の濃度は図-5 のような変化を示 す.ここで, 濃度変化が定常になったときの傾きを $\mathrm{Cl}^{-}$の透過速度 $\Delta \mathrm{Q}_{\mathrm{i}}(\mathrm{mol} / / \cdot \mathrm{sec})$ と呼ぶ. 透過速度 $\Delta$ $\mathrm{Q}_{\mathrm{i}}$ とフラックス $\mathrm{J}_{\mathrm{i}}\left(\mathrm{mol} / \mathrm{cm}^{2} \cdot \mathrm{sec}\right.$ : 単位時間・単位面 積あたりの物質通過量)は次に示す関係があるので, 濃度変化よりフラックスが算出できる [式 5.1］。

$$
J_{i}=\Delta Q_{i} \cdot \frac{V_{\text {cell }}}{A}
$$


ただし, A は供試体の断面積 $\mathrm{V}_{\text {cell }}$ は被検出セル中 の溶液量を示す。

\section{(2) Nernst-Plank の式について}

水溶液中の電気化学的な物質移動に関する一般式 である Nernst-Plank の式は, 希薄溶液中におけるイ オン $\mathrm{i}$ の拡散係数 $\mathrm{D}_{\mathrm{i}}$, 濃度 $\mathrm{C}_{\mathrm{i}}$, 電気的移動度 $\mathrm{u}_{\mathrm{i}}$ およ び静電ポテンシャル中を用いると, 次のように表され る[式 5.2].

$$
J_{i}=-D_{i} \cdot \frac{d C_{i}}{d x}-u_{i} \cdot C_{i} \cdot \frac{d \phi}{d x}
$$

第 1 項は Fick の法則を表す。これは，濃度勾配が 駆動力になっている拡散に関する項である. 第 2 項 は静電ポテンシャル勾配（以下，電位勾配）が駆動 力になっている電気泳動に関する項である.

拡散時は，電位勾配と関係する第 2 項が小さいと して無視すると, 次の関係式が成立する [式 5.3].

$$
\begin{aligned}
J_{i} & =-D_{i} \cdot \frac{d C_{i}}{d x} \\
\therefore D_{i} & =-J_{i} \cdot \frac{1}{d C_{i} / d x}
\end{aligned}
$$

このことから, $\mathrm{Cl}^{-}$のフラックスおよび $\mathrm{Cl}^{-}$の濃 度勾配を測定することにより， $\mathrm{Cl}^{-}$の拡散係数が算 出できる.

また，電気泳動時は濃度勾配による移動を表す第 1 項と比較して, 外部から与えた電位勾配による移 動が第 2 項が卓越するうので, フラックス $\mathrm{J}_{\mathrm{i}}$, 溶液の 濃度 $\mathrm{C}_{\mathrm{i}}$, 供試体にかかる電位勾配 $\mathrm{d} \phi / \mathrm{dx}$ を測定する ことにより電気的移動度 $u_{i}$ が算出できる［式 5.4］。

$$
\begin{aligned}
J_{i} & =-u_{i} \cdot C_{i} \cdot \frac{d \phi}{d x} \\
\therefore u_{i} & =-\frac{J_{i}}{C_{i}} \cdot \frac{1}{d \phi / d x}
\end{aligned}
$$

その電気的移動度 $u_{i}$ に対して, 次に示す Einstein の関係式を用いると, 電気的移動度 $\mathbf{u}_{\mathrm{i}}$ は拡散係数 $\mathrm{D}_{\mathrm{i}}$ に変換できる ${ }^{6}$ ので, 電気泳動実験から拡散係数を 理論的に算出できる [式 5.5］。

$$
D_{i}=\frac{k \cdot T}{e \cdot Z_{i}} \cdot u_{i}
$$

\begin{tabular}{|c|c|c|c|c|}
\hline \multirow[b]{2}{*}{$\mathrm{W} / \mathrm{C}$} & \multirow{2}{*}{$\begin{array}{c}\text { 添加 } \\
\mathrm{NaOH} \\
\left(\mathrm{kmol} / \mathrm{m}^{3}\right)\end{array}$} & \multicolumn{2}{|c|}{ 電気泳動セル実験 } & 拡散実験 \\
\hline & & $\begin{array}{l}\text { 電気的 } \\
\text { 移動度* }\end{array}$ & $\begin{array}{c}\text { 拡散係数 } \\
* *\end{array}$ & $\begin{array}{c}\text { 拡散係数 } \\
* *\end{array}$ \\
\hline 0.40 & 0.00 & 1.780 & 4.500 & 2.130 \\
\hline 0.50 & 0.00 & 2.491 & 6.290 & 4.660 \\
\hline 0.65 & 0.00 & 4.094 & 10.300 & 8.680 \\
\hline 0.40 & 0.13 & 1.495 & 3.780 & 0.435 \\
\hline 0.50 & 0.13 & 2.024 & 5.110 & 0.806 \\
\hline 0.65 & 0.13 & 2.556 & 6.460 & 4.330 \\
\hline 0.40 & 0.26 & 0.987 & 2.500 & 0.002 \\
\hline 0.50 & 0.26 & 1.222 & 3.090 & 0.025 \\
\hline 0.65 & 0.26 & 2.123 & 4.780 & 0.655 \\
\hline
\end{tabular}

ただし， $\mathrm{k}$ はボルツマン定数， T は絶対温度， e は 電気素量, $Z_{\mathrm{i}}$ は着目イオン $\mathrm{i}$ の価数である.
表-5 電気泳動セル実験で得られた電気的移動度および 拡散係数と拡散セル実験で得られた拡散係数の一覧

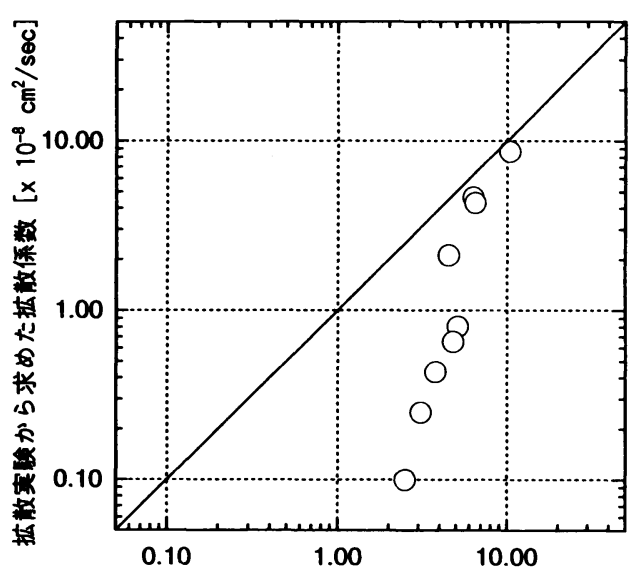

泳動実臤から求めた拡散係数 $\left[\times 10^{-8} \mathrm{~cm}^{2} / \mathrm{sec}\right]$

図-6 Einsteinの関係式を用いて整理した場合の 搪散保数の比較

6. 電気泳動と拡散の関連性に関する考察 (Einstein の関係式を用いた場合)

\section{(1) 実験結果の整理}

表-5 に，本研究における電気泳動セル実験で得ら れた電気的移動度およびこれにより算出された拡散 係数之，拡散セル実験で得られた拡散係数の一覧を 示す.これらの結果を用いて以下の考察を行う.

(2) Einstein の関係式を用いた場合の考察

電気泳動実験より $\mathrm{Cl}^{-}$の拡散係数を Einstein の式 
表-6 硬化体細孔溶液中の各種イオン濃度, イオン強度の算出結果と補正係数 $\left(1+\partial \ln \gamma / \partial \ln C_{C l}\right)$

\begin{tabular}{|c|c|c|c|c|c|c|c|c|}
\hline $\mathrm{W} / \mathrm{C}$ & \begin{tabular}{|c|} 
添加 $\mathrm{NaOH}$ \\
$(\mathrm{mol} / \mathrm{l})$
\end{tabular} & $\begin{array}{l}\mathrm{C}_{\mathrm{Na}}+ \\
(\mathrm{mol} / \mathrm{l})\end{array}$ & $\begin{array}{c}\mathrm{C}_{\mathrm{K}}+ \\
(\mathrm{mol} / \mathrm{l})\end{array}$ & $\begin{array}{l}\mathrm{C}_{\mathrm{Ca} 2}+ \\
(\mathrm{mol} / \mathrm{l})\end{array}$ & $\begin{array}{l}\mathrm{C}_{\mathrm{Cl}}- \\
(\mathrm{mol} / \mathrm{l})\end{array}$ & $\begin{array}{l}\mathrm{C}_{\mathrm{OH}}- \\
(\mathrm{mol} / \mathrm{l})\end{array}$ & $\begin{array}{c}\text { イオン強度 } \\
\mathrm{I} \\
(\mathrm{mol} / \mathrm{l})\end{array}$ & $\begin{array}{l}\text { 補正係数 } \\
1+\frac{\partial \ln \gamma}{\partial \ln C_{C l}}\end{array}$ \\
\hline 0.40 & 0.00 & 0.257 & 0.022 & 0.003 & 0.651 & 0.064 & 0.991 & 0.805 \\
\hline 0.50 & 0.00 & 0.236 & 0.018 & 0.003 & 0.575 & 0.050 & 0.883 & 0.807 \\
\hline 0.65 & 0.00 & 0.215 & 0.020 & 0.003 & 0.514 & 0.060 & 0.807 & 0.811 \\
\hline 0.40 & 0.13 & 0.336 & 0.025 & 0.002 & 0.667 & 0.124 & 1.143 & 0.827 \\
\hline 0.50 & 0.13 & 0.298 & 0.026 & 0.003 & 0.573 & 0.137 & 1.032 & 0.835 \\
\hline 0.65 & 0.13 & 0.236 & 0.025 & 0.002 & 0.486 & 0.144 & 0.878 & 0.836 \\
\hline 0.40 & 0.26 & 0.382 & 0.021 & 0.003 & 0.647 & 0.187 & 1.231 & 0.844 \\
\hline 0.50 & 0.26 & 0.327 & 0.020 & 0.002 & 0.561 & 0.204 & 1.113 & 0.850 \\
\hline 0.65 & 0.26 & 0.306 & 0.018 & 0.004 & 0.491 & 0.192 & 1.017 & 0.857 \\
\hline
\end{tabular}

により算出することができる. しかし，拡散実験か ら求めた $\mathrm{Cl}^{-}$の拡散係数（以下，拡散実験における 拡散係数）と電気泳動実験から求めた移動度を関係 式に代入して求めた $\mathrm{Cl}^{-}$の拡散係数（以下，電気泳 動実験より得られる移動度に関係式を適用して求め た拡散係数) は，図-6のような関係になり，それら の間に関連性がみられるものの特に拡散係数が小さ い領域で大きく異なる傾向がみられた.

以上より, 電気泳動セル実験よりコンクリートの 拡散係数を推計する際に Einstein の関係式を用いた 場合には, ある程度の相関性が得られるものの, そ の精度はあまり良くないことがわかった。

\section{7. 細孔溶液濃度を考慮した電気泳動と拡散の 関連性に関する考察}

(Debye-Hückel の理論を用いた場合)

5-(2)で示した Nernst-Plank 式は希薄溶液中での式 であり，濃度が無視できないすなわち一般的な溶液 やでは次のように表される ${ }^{8)}$ [式 7.1］

$$
\begin{aligned}
J_{i}=-k \cdot T \cdot B_{i} & \cdot\left(1+\frac{\partial \ln \gamma}{\partial \ln C_{i}}\right) \cdot \frac{d C_{i}}{d x} \\
& -e \cdot Z_{i} \cdot C_{i} \cdot B_{i} \cdot \frac{d \phi}{d x}
\end{aligned}
$$

ただし，k，T，e， $Z_{i}$ および $\gamma$ は，それぞれボル ツマン定数, 絶対温度, 電気素量, イオンの価数お よび水溶液中におけるイオンの活量係数を示す.

(7.1) と(5.2) との比較により, $\mathrm{Cl}^{-}$の搪散係数 $\mathrm{D}_{\mathrm{i}}$ と 絶対移動度 $\mathrm{B}_{i}$ には，以下の関係があることがわかる。

$$
D_{i}=k \cdot T \cdot B_{i} \cdot\left(1+\frac{\partial \ln \gamma}{\partial \ln C_{i}}\right)
$$

Fick の法則から求められる拡散係数 $\mathrm{D}_{\mathrm{i}}$ は, 温度お よび活量係数 $\gamma$ の関数であることがわかる. また, (7.1)によると濃度勾配による移動も電位勾配による 移動も 1 つの移動指標, 絶対移動度 $\mathrm{B}_{\mathrm{i}}$ で表されてい ることがわかる.すなわち, 電気泳動セル実験から 拡散係数を推計する場合には, 移動指標として絶対 移動度 $\mathrm{B}_{\mathrm{i}}$ を用い，溶液の濃度に関する補正係数 $\left(1+\partial \ln \gamma / \partial \ln C_{i}\right)$ を算出して，これを考虑して拡散係 数を求めることが適当であると考えられる.

ここで, 絶対移動度 $\mathrm{B}_{\mathrm{i}}\left(\mathrm{cm}^{2} \cdot \mathrm{sec}^{-1} \cdot\right.$ dyne $\left.\mathrm{e}^{-1}\right)$ は, 単位推進力当たりに生じる移動速度 $\left(\mathrm{cm} \cdot \mathrm{sec}^{-1}\right)$ で あり, 電気的移動度 $u_{i}$ と絶対移動度 $B_{i}$ は, (7.1) と(5.2) との比較により以下の関係がある [式 7.3］。

$$
B_{i}=\frac{u_{i}}{e \cdot Z_{i}}
$$

また, 活量係数 $\gamma$ は, 溶液化学における電解質溶 液論 ${ }^{6)}$ によると以下のように表される［式 7.4］。

$$
\log \gamma=\frac{-A \cdot\left|Z_{+} \cdot Z_{-}\right| \cdot \sqrt{I}}{1+B \cdot a \cdot \sqrt{I}}
$$

$$
\begin{aligned}
\text { ここに, } & \mathrm{A}=0.5115\left(\mathrm{~mol}^{-1 / 2} \cdot \mathrm{dm}^{3 / 2}\right) \\
& \mathrm{B}=0.3921 \times 10^{8}\left(\mathrm{~mol}^{-1 / 2} \cdot \mathrm{dm}^{3 / 2}\right) \\
& \mathrm{a}=3 \times 10^{-8}\left(\mathrm{~cm}, \mathrm{Cl}^{-}\right), 4 \times 10^{-8}\left(\mathrm{~cm}, \mathrm{Na}^{+}\right)
\end{aligned}
$$




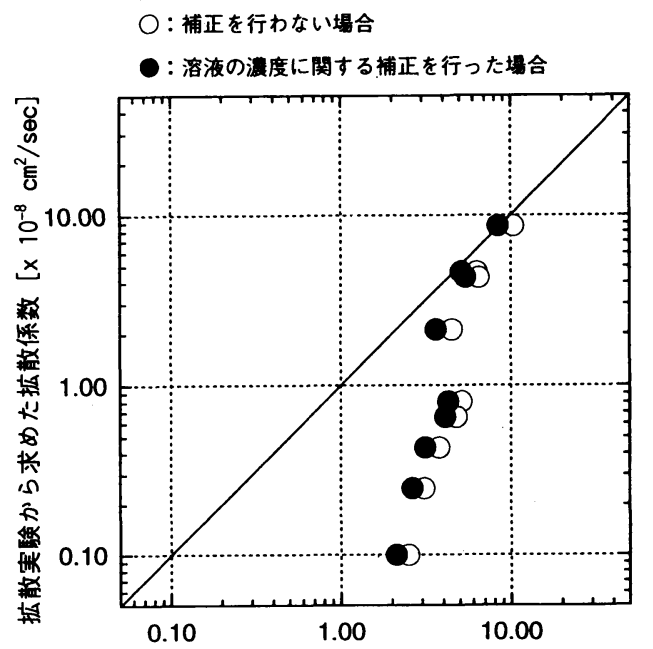

泳動実験から求めた拡散係数 $\left[x \quad 10^{-8} \mathrm{~cm}^{2} / \mathrm{sec}\right]$

図-7 Debye-Hückel の理論に基づいて整理した場合の 拡散係数の比較

(7.4)は Debye-Hückel の理論式と呼ばれているもの である.ここで， $\left|Z_{+} \cdot Z_{-}\right|$は陽イオンおよび㓌イオ ンの価数の積の絶対值, A, B は定数, a はイオンサ イズパラメータである.

また，イオン強度 I は次式で定義される [式 7.5］。

$$
I=\frac{1}{2} \sum Z_{i}^{2} \cdot C_{i}
$$

これは，いうなれば静電気的な効果の重みをかけ たイオンの総濃度（単位： $\mathrm{mol} / \mathrm{l}$ ) といえる.

本研究で用いた各供試体の細孔溶液濃度を測定し, これらより求めたイオン強度ならびに溶液中のイオ ン濃度に関する補正係数 $\left(1+\partial \ln \gamma / \partial \ln C_{i}\right)$ の算出結 果を表-6 に示す.

また，図一7は，絶対移動度 $\mathrm{B}_{\mathrm{I}}$ を用い, Debye-Hückel の理論に基づいて, 溶液中のイオン濃度に関する補 正係数 $\left(1+\partial \ln \gamma / \partial \ln C_{i}\right)$ を考慮して電気泳動セル実 験から算出した拡散係数と，拡散セル実験によって 求められた搪散係数を比較したものである.これに よると，拡散実験における拡散係数と電気泳動実験 より得られる絶対移動度に関係式を適用して求めた 抬散係数に対して若干の補正が行われるが，電気泳 動実験による拡散係数が未だにかなり大きく評価し ていることがわかる。すなわち，細孔溶液濃度の影 響を考慮するのみでは，十分な補正を行うことが困 難であると言える.

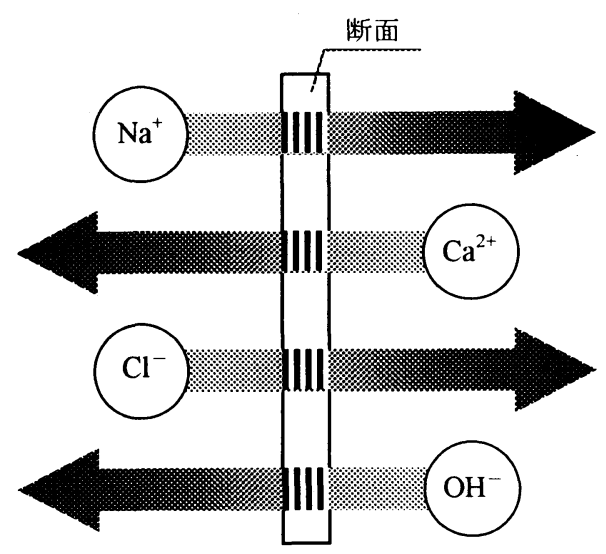

$\mathrm{NaCl}-5 \%$ 水溶液

$\mathrm{Ca}(\mathrm{OH})_{2}$ 飽和水溶液

図-8 拡散時におけるイオンの移動方向の説明

\section{8. 電気的中性条件を考慮した電気泳動と拡散 の関連性に関する考察}

6-(2)で，細孔溶液の濃度による影響を考虑するだ けでは，拡散と電気泳動の関係を明らかにすること はできなかった.そこで, Nernst-Plank 式とともに移 動現象を支配する式である電気的中性について考慮 することを試みた。電気的中性は次の式で表される 関係式である [式 8.1].

$$
\sum_{i} Z_{i} \cdot J_{i}=0
$$

(8.1)は，ある断面を通過する陽イオンおよび㓌イ オンは, 電気的に中性を保つように移動しなければ ならないことを示している。

また，(7.1)を(8.1)に代入し，電位勾配に関して整 理すると，それぞれのイオンに関する Nernst-Plank 式は次式になる [式 8.2］.

$$
\frac{d \phi}{d x}=\frac{\sum_{i} Z_{i} \cdot\left(1+\frac{\partial \ln \gamma}{\partial \ln C_{i}}\right) \cdot B_{i} \cdot \frac{\partial C_{i}}{\partial x}}{\sum_{i} Z_{i}^{2} \cdot B_{i} \cdot C_{i}} \cdot \frac{k \cdot T}{e}
$$

(8.2)を(7.1)に代入することにより，本研究におい て着目している $\mathrm{Cl}^{-}$に関する Nernst-Plank 式は, 影 響を及ぼすイオンとして $\mathrm{OH}^{-}, \mathrm{Na}^{\dagger}$ および $\mathrm{K}^{+}$を 
表-7 細孔溶液中の各種イオン濃度の比と電気的中性条件による補正係数の算出結果

\begin{tabular}{c|c|c|c|c|c|c}
\hline $\mathrm{W} / \mathrm{C}$ & $\begin{array}{c}\text { 添加 NaOH } \\
(\mathrm{mol} / \mathrm{l})\end{array}$ & $\mathrm{C}_{\mathrm{Na}}+\mathrm{C}_{\mathrm{Cl}}$ & $\mathrm{C}_{\mathrm{K}_{+}} / \mathrm{C}_{\mathrm{Cl}}-$ & $\mathrm{C}_{\mathrm{Ca} 2} / \mathrm{C}_{\mathrm{Cl}_{-}}$ & $\mathrm{C}_{\mathrm{OH}} / \mathrm{C}_{\mathrm{Cl}}-$ & 補正係数 \\
\hline 0.40 & 0 & 0.395 & 0.028 & 0.004 & 0.113 & 0.65 \\
\hline 0.50 & 0 & 0.410 & 0.037 & 0.004 & 0.084 & 0.68 \\
\hline 0.65 & 0 & 0.417 & 0.034 & 0.006 & 0.097 & 0.70 \\
\hline 0.40 & 0.13 & 0.504 & 0.022 & 0.004 & 0.283 & 0.40 \\
\hline 0.50 & 0.13 & 0.520 & 0.039 & 0.005 & 0.235 & 0.50 \\
\hline 0.65 & 0.13 & 0.485 & 0.033 & 0.005 & 0.184 & 0.55 \\
\hline 0.40 & 0.26 & 0.590 & 0.028 & 0.004 & 0.408 & 0.18 \\
\hline 0.50 & 0.26 & 0.582 & 0.036 & 0.004 & 0.361 & 0.20 \\
\hline 0.65 & 0.26 & 0.623 & 0.031 & 0.009 & 0.281 & 0.40 \\
\hline
\end{tabular}

O：補正を行わない場合

○：溶液の湭度ならびに電気的中性条件 に関する㭪正を行った塂合

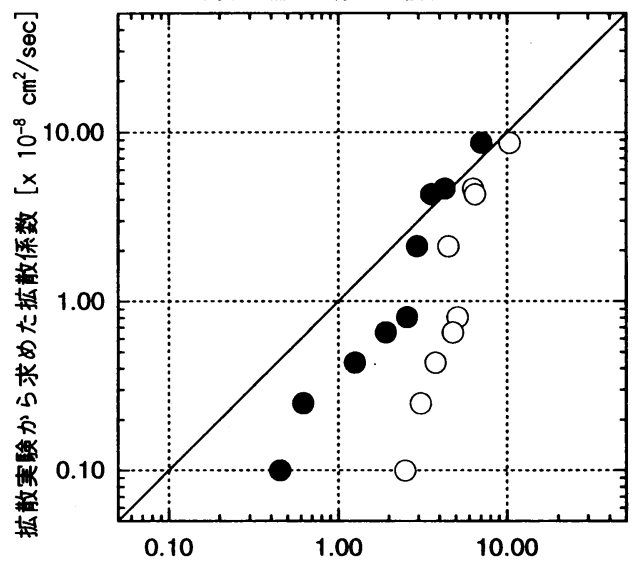

泳動実倹から求めた拡散係数 $\left[\mathrm{x} 10^{-8} \mathrm{~cm}^{2} / \mathrm{sec}\right]$

図-9 電気的中性条件を考慮して整理した場合の 拡散係数の比較

考慮し，次のように変形することができる $[$ 式 8.3$]$.

$$
\begin{aligned}
J_{C l} & =-k \cdot T \cdot B_{C l} \cdot\left\{\left(1+\frac{\partial \ln \gamma}{\partial \ln C_{C l}}\right)\right. \\
& \left.+\frac{\sum_{i} Z_{C l} \cdot Z_{i} \cdot\left(1+\frac{\partial \ln \gamma}{\partial \ln C_{i}}\right) \cdot B_{i} \cdot C_{C l} \cdot \frac{\partial C_{i} / \partial x}{\partial C_{C l} / \partial x}}{\sum_{i} Z_{i}^{2} \cdot B_{i} \cdot C_{i}}\right\} \cdot \frac{d C_{C l}}{d x}
\end{aligned}
$$

つまり, Fick の拡散係数 $\mathrm{D}_{\mathrm{i}}$ は次のように表される ことになり,これが電気泳動と拡散を関連つける式 だと考えられる［式 8.4］。

$$
\begin{aligned}
D_{C l} & =k \cdot T \cdot B_{C l} \cdot\left\{\left(1+\frac{\partial \ln \gamma}{\partial \ln C_{i}}\right)\right. \\
& \left.+\frac{\sum_{i} Z_{C l} \cdot Z_{i} \cdot\left(1+\frac{\partial \ln \gamma}{\partial \ln C_{i}}\right) \cdot B_{i} \cdot C_{C l} \cdot \frac{\partial C_{i} / \partial x}{\partial C_{C l} / \partial x}}{\sum_{i} Z_{i}^{2} \cdot B_{i} \cdot C_{i}}\right\}
\end{aligned}
$$

表-7に, 本研究で用いた供試体の細孔溶液濃度に 関する計算結果ならびにこれらより算出される補正 係数（式(8.4)中の\{ \}で囲まれた部分）を示す．ま た，それぞれのイオンが図-8のような動きを示すこ とに注意して，式(8.4)を用い，電気泳動実験から得 られた絶対移動度 $\mathrm{B}_{\mathrm{i}}$ から拡散係数 $\mathrm{D}_{\mathrm{i}}$ の算出を行っ た.

図-9に，関係式として(8.4)を用いて整理した拡散 係数の関係を示す. 図-7 と比較すると，電気泳動な らびに拡散実験によるそれぞれの拡散係数において， おおむね相関性が得られるようである.これは(8.4) が他のイオン濃度の影響をより的確に考慮している ためであると考えられる. しかしながら，図-9によ れば, $10^{-9}$ オーダーのような小さな拡散係数の場合 に，それぞれの拡散係数のずれが大きくなる傾向が あり，採取溶液の適切なサンプリング方法など，よ り精緻な測定とするための方法論も含めて，さらに 詳細な検討を要するものと考えられる. 


\section{9. 結論}

本研究では，モルタル中における $\mathrm{Cl}^{-}$の拡散係数 を電気泳動実験により理論的に精度よく推定できる 方法を提案し, ある程度検証し得た。

すなわち，電気泳動実験から得られる絶対移動度 と拡散実験から得られる拡散係数とを結びつける関 係式を理論的に導き出し，また，実験的に検証する ことにより，コンクリート中における $\mathrm{Cl}^{-}$の電気泳 動および拡散の関連性について検討を行った。 その 結果以下のことが明らかになった。

（1）希薄溶液中における Einstein の関係に関する考 え方から，イオンの濃度および電気的中性条件を 考虑しなくとも，コンクリート中における $\mathrm{Cl}^{-}$ の拡散係数を推計することが可能であるが, その 精度は低い。

（2）溶液中の電解質濃度を考慮し， Debye-Hückel の 理論を導入することにより,コンクリート中にお ける $\mathrm{Cl}^{-}$の拡散係数を推計することが可能であ り，その精度は(1)の場合よりも若干向上する。し かしながら,この程度の補正では, 精度の良い推 計は困難である.

(3) Debye-Hückel の理論に加え，溶液中における電 気的中性条件を導入することにより，コンクリー 卜中における $\mathrm{Cl}^{-}$の拡散係数を推計することが 可能であり, その精度は大幅に向上し, ある程度 の精度の良い推計が可能となる。
以上より, 本研究を通じて, Einstein の関係式の他 に,イオンの濃度の影響ならびに電気的中性条件を 導入することにより, コンクリート中の $\mathrm{Cl}^{-}$の拡散 係数を推計する実験定数を含まない理論式を導くこ とができた. さらに，モルタルの電気泳動実験およ び拡散実験を通じて，導出した理論式が精度よく適 用可能であることを明らかにすることができた。

\section{参考文献}

1）例えば，岸谷孝一ら：コンクリート構造物の耐久性シ リーズ／塩害（I），技報堂出版。pp.23-37，1986。

2) 例えば, 近藤連一，佐竹 実, 牛山宏隆 : セメント硬 化体中のイオン拡散，セメント技術年報、No.28， pp.58-61, 1974.

3) ASTM C 1202-1991: Standard Test Method for Electrical Indication of Concrete's Ability to Resist Chloride Ion Penetration.

4) Andrade C. : Calculation of Chloride Diffusion Coefficients In Concrete from Ionic Migration Measurement, Cement and Concrete Research, Vol.23, No.3, 1993

5) 長瀧重義, 大即信明, 久田 真, 遠藤 平 : コンクリ 一ト中のイオンの通電泳動に関する研究。土木学会論 文集, No.520/V-28, pp.77-86, 1995.

6) Bockris, J. O' M. and Reddy A. K. N. : Modern Electrochemistry, Vol.1, Plenum/Rosetta, pp.374-377, 1973.

7) 花井哲也著 : 膜とイオンー物質移動の理論と計算一, 化学同人, pp.65-68, 1978.

8) 電気化学協会編:電気化学便覧(第 4 版), 丸善, pp.84-87, 1985.

(1997. 5.28 受付)

\title{
THEORETICAL ASSESSMENT OF DIFFUSION COEFFICIENT OF CHLORIDE ION IN MORTAR BY ELECTRO-MIGRATION METHOD
}

\author{
Nobuaki OTSUKI, Makoto HISADA, Takayuki OTANI and Toshio MARUYAMA
}

Diffusion and electro-migration of ion in electrolyte solution, can be theoretically described by the Nernst-Plank equation. Also, diffusion and migration of ion can be related by using Einstein's relation. However, the relationship between diffusion and electro-migration in concrete are still unclear. In this paper, the authors tried to assess diffusion coefficient of chloride ion in concrete from the test results of ion electro-migration through concrete, by following the Nernst-Plank equation, Einstein's relation, Debye-Hückel theory and electro neutrality. Through these investigation, it can be clarified that the influence of concentration and moving direction of ion in concrete should be noticed in assessing of diffusion coefficient of chloride ion from electro-migration of ion through concrete. 